\title{
An Adult Case of Fulminant Epstein-Barr Virus Infection with Acute Tubulointerstitial Nephritis
}

\author{
Jun Suzuki, Takanori Komada, Keiji Hirai, Hirohisa Tsuruoka, Honami Mori, \\ Izumi Yoshida and Kaoru Tabei
}

\begin{abstract}
Epstein-Barr virus (EBV) infection is common in adolescence, but fulminant infection is very rare. A 40year-old man presented with high fever and sore throat. Symptoms, including cervical lymphadenopathy, jaundice, atypical lymphocytosis, respiratory distress and oliguria, suggested infectious mononucleosis with multiple organ failure that required mechanical ventilation and renal replacement therapy. Virus markers were consistent with primary EBV infection. Renal function was gradually improved by corticosteroid therapy. Renal biopsy revealed acute tubulointerstitial nephritis. In situ hybridizaion EBV-encoded RNA 1 did not show the presence of virus in the kidney, but acute kidney injury may be explained by cytotoxic/suppressor $\mathrm{T}$ lymphocyte infiltration,
\end{abstract}

Key words: fulminant Epstein-Barr virus infection, infectious mononucleosis, corticosteroid, acute tubulointerstitial nephritis

(Intern Med 51: 629-634, 2012)

(DOI: 10.2169/internalmedicine.51.6299)

\section{Introduction}

Infectious mononucleosis due to Epstein-Barr virus (EBV) is common in adolescence and generally has an excellent prognosis. Fulminant infection, by contrast, is very rare. Associated with this are some published reports of fatal complications such as secondary hemophagocytic lymphohistiocytosis, hepatic failure, lymphoproliferative disorders and acute kidney injury (AKI) (1).

We present here a case of fulminant infectious mononucleosis with AKI in a previously healthy man. Our case did not have hemophagocytosis, but multiple organ failure occurred abruptly. Oliguric AKI, caused by biopsy proven acute tubulointerstitial nephritis, necessitated renal replacement therapy.

\section{Case Report}

A previously healthy 40-year-old Japanese man presented to a local clinic with sudden onset of high fever, sore throat and anorexia in May 2010. He was diagnosed with tonsillitis and oral antibiotic (cefditoren pivoxil) was prescribed but his condition worsened. He noticed bilateral swollen tonsils, cervical lymphadenopathy and jaundice. Five days later, he was admitted to a local hospital where he was administered flomoxef sodium and clindamycin. However his general conditions worsened with development of frequent watery diarrhea, arthralgia and myalgia. Laboratory data showed elevated total bilirubin $(8.6 \mathrm{mg} / \mathrm{dl})$ and increased serum creatinine $(5.0 \mathrm{mg} / \mathrm{dl})$ on the 4th hospital day. And a peripheral blood smear revealed atypical lymphocytosis. Infectious mononucleosis with multiple organ failure was suspected and he was transferred to our medical center on the same day.

Following a left femoral fracture about 10 years ago he received a blood transfusion. He did not take medications regularly, had no known allergies, and did not smoke, drink alcohol or use intravenous drugs. He denied any sexual intercourse with other than one steady partner. His mother had rheumatoid arthritis.

Physical examinations on admission showed an illappearing man. Height was $171 \mathrm{~cm}$, body weight $91 \mathrm{~kg}$, body temperature $38.6^{\circ} \mathrm{C}$, blood pressure $119 / 72 \mathrm{mmHg}$, 
Table 1. Laboratory Data on Admission

\begin{tabular}{|c|c|c|c|c|c|c|c|c|c|c|c|}
\hline$\langle$ Hematology $\rangle$ & & & |Serum Chemistries $\rangle$ & & & |Serology $\rangle$ & & & 〈Urinanalysis $\rangle$ & & \\
\hline WBC & 19.45 & $\times 10^{3} / \mu \mathrm{L}$ & Protein,total & 6.2 & $\mathrm{~g} / \mathrm{dL}$ & CRP & 4.93 & $\mathrm{mg} / \mathrm{dL}$ & Specific Gravity & 1.006 & \\
\hline neutrophil & 22.5 & $\%$ & Albumin & 1.8 & $\mathrm{~g} / \mathrm{dL}$ & $\lg G$ & 2970 & $\mathrm{mg} / \mathrm{dL}$ & $\mathrm{pH}$ & 6.0 & \\
\hline lymphocyte & 50 & $\%$ & Bilirubin,total & 7.14 & $\mathrm{mg} / \mathrm{dL}$ & $\operatorname{Ig} A$ & 570 & $\mathrm{mg} / \mathrm{dL}$ & Protein & $1+$ & \\
\hline monocyte & 3 & $\%$ & Bilirubin,conjugated & 5.65 & $\mathrm{mg} / \mathrm{dL}$ & IgM & 299 & $\mathrm{mg} / \mathrm{dL}$ & & 0.58 & g/day \\
\hline eosinophil & 0 & $\%$ & AST & 267 & $\mathrm{mU} / \mathrm{mL}$ & $\mathrm{C} 3$ & 47 & $\mathrm{mg} / \mathrm{dL}$ & Glucose & - & \\
\hline basophil & 1 & $\%$ & ALT & 178 & $\mathrm{mU} / \mathrm{mL}$ & $\mathrm{C} 4$ & 23 & $\mathrm{mg} / \mathrm{dL}$ & Bilirubin & $1+$ & \\
\hline myelo & 3 & $\%$ & LDH & 1251 & $\mathrm{mU} / \mathrm{mL}$ & $\mathrm{CH} 50$ & 16.7 & $\mathrm{U} / \mathrm{mL}$ & Occult Blood & $1+$ & \\
\hline $\begin{array}{l}\text { meta } \\
\text { atypical }\end{array}$ & 0.5 & $\%$ & ALP & 1461 & $\mathrm{mU} / \mathrm{mL}$ & ANA & \pm & & Leucocyte & - & \\
\hline lymphocyte & 20 & $\%$ & GGT & 501 & $\mathrm{mU} / \mathrm{mL}$ & PR3-ANCA & $<10$ & & beta $2 \mathrm{MG}$ & 17947 & $\mu \mathrm{g} / \mathrm{L}$ \\
\hline $\mathrm{RBC}$ & 396 & $\times 10^{4} / \mu \mathrm{L}$ & Amylase & 33 & $\mathrm{mU} / \mathrm{mL}$ & MPO-ANCA & $<10$ & & NAG & 17.5 & IU/L \\
\hline Hemoglobin & 11.6 & $\mathrm{~g} / \mathrm{dL}$ & Sodium & 124 & $\mathrm{mmol} / \mathrm{L}$ & & & & & & \\
\hline Hematocrit & 32.4 & $\%$ & Potassium & 4 & $\mathrm{mmol} / \mathrm{L}$ & $\langle$ Virus markers $\rangle$ & & & KArterial Blood C & Gases> & \\
\hline MCV & 81.8 & $\mathrm{fl}$ & Chloride & 94 & $\mathrm{mmol} / \mathrm{L}$ & IgM-HA antibody & $<0.40$ & & (room air) & & \\
\hline $\mathrm{MCHC}$ & 35.8 & $\mathrm{~g} / \mathrm{dL}$ & Calcium & 6.6 & $\mathrm{mg} / \mathrm{dL}$ & HBs antigen & $(-)$ & & $\mathrm{pH}$ & 7.416 & \\
\hline Platelet & 8 & $\times 10^{4} / \mu \mathrm{L}$ & Phosphate & 5.5 & $\mathrm{mg} / \mathrm{dL}$ & HCV antibody & $(-)$ & & $\mathrm{PaO}_{2}$ & 71.3 & Torr \\
\hline PT-INR & 2.21 & & Urea nitrogen & 50 & $\mathrm{mg} / \mathrm{dL}$ & EBV-VCA IgG(IFA) & $1: 320$ & & $\mathrm{PaCO}_{2}$ & 37.1 & Torr \\
\hline aPTT & 54.1 & sec. & Creatinine & 5.31 & $\mathrm{mg} / \mathrm{dL}$ & EBV-VCA IgM(IFA) & $1: 40$ & & $\mathrm{HCO}_{3}^{-}$ & 23.3 & $\mathrm{mmol} / \mathrm{L}$ \\
\hline \multirow[t]{6}{*}{ Fibrinogen } & 125 & $\mathrm{mg} / \mathrm{dL}$ & Uric acid & 17.7 & $\mathrm{mg} / \mathrm{dL}$ & EBNA IgG(IFA) & $1: 10$ & & & & \\
\hline & & & Glucose & 210 & $\mathrm{mg} / \mathrm{dL}$ & EBV DNA(RT-PCR) & $1.5 \times 10^{5}$ & copies $/ 10^{6}$ cells & & & \\
\hline & & & Total Cholesterol & 142 & $\mathrm{mg} / \mathrm{dL}$ & CMV IgG(EIA) & $56.6(+)$ & & & & \\
\hline & & & Triglyceride & 271 & $\mathrm{mg} / \mathrm{dL}$ & CMV IgM(EIA) & $1.08( \pm)$ & & & & \\
\hline & & & & & & HIV antibody & $(-)$ & & & & \\
\hline & & & & & & CMV pp65(C10,C11) & $(-)$ & & & & \\
\hline
\end{tabular}

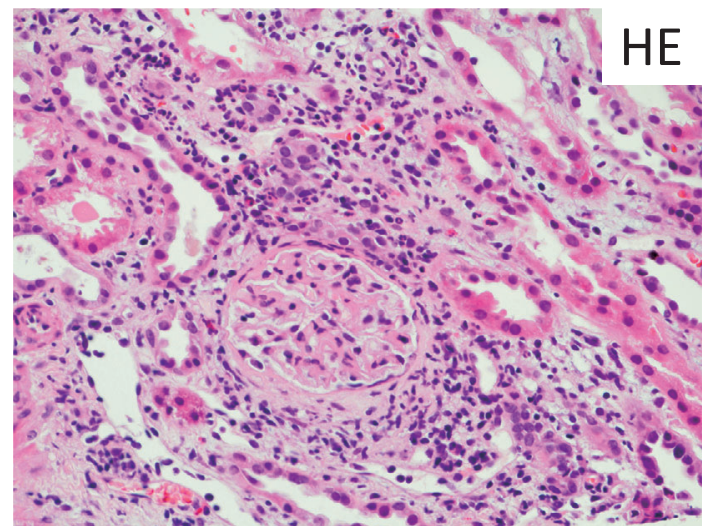

Figure 1. Histology of biopsy specimens (Hematoxylin and Eosin staining $\times 200$ ) showing lymphocyte infiltration in the interstitial space among 20 normal glomeruli.

heart rate $98 \mathrm{bpm}$ with regular rhythm, and respiratory rate was 30/minute. Small erythematous eruptions were seen with a symmetrical distribution on his legs and trunk. Conjunctivae were pale and icteric. Cervical lymph nodes were enlarged bilaterally. Heart sounds were unremarkable. Coarse crackles were audible in both lung fields. Hepatosplenomegaly was present, the liver edge was palpable 2 $\mathrm{cm}$ below the right costal margin and was tender. There was bilateral pretibial pitting edema.

Laboratory data are shown in Table 1. Atypical lymphocytosis was seen, and serum chemistries indicated renal insufficiency, hepatic failure and respiratory failure. Arterial blood gas analysis with $2 \mathrm{~L} / \mathrm{min}$ oxygen by nasal cannula showed low partial pressure of oxygen but acid-base balance was compensated. Urinalysis showed only trace proteinuria and 1+ occult blood. Anti-hepatitis virus antibodies, cytomegalovirus antigenemia and human herpes virus 6 DNA were absent. Serum levels of EBV markers indicated primary EBV infection. Chest X-ray showed bilateral pleural effusion and hepatosplenomegaly was seen on abdominal ultrasonography and CT scan.

The presence of thrombocytopenia, hepatic dysfunction and rash seemed to be due to virus-induced hemophagocytic syndrome but bone marrow aspiration revealed no sign of hemophagocytosis. There was no neoplastic proliferation and CD8+ T lymphocytes were dominant in the bone marrow. Continuous renal replacement therapy and mechanical ventilation were required. Due to the multiple organ damage, we started corticosteroid therapy with prednisolone ( 80 $\mathrm{mg}$ a day) with $10 \mathrm{mg}$ reduction every 3 days, according to a previously reported regimen (2). Jaundice and skin eruptions improved and urinary output gradually increased. After his vital signs had stabilized and ventilation support was discontinued, we performed renal biopsy on the 18thhospital day to investigate the cause of AKI.

Many lymphocytes infiltrated the interstitial space among 20 normal glomeruli (Fig. 1). Immunofluorescence study was negative for IgG/A/M, C3c, C4, C1q and fibrinogen. Lymphocytes infiltrating the tubulointerstitial space were mostly CD3+CD8+ and CD68+ by immunoenzymatic staining (Fig. 2, 3). There were few $\mathrm{CD} 3+\mathrm{CD} 4+$ lymphocytes 


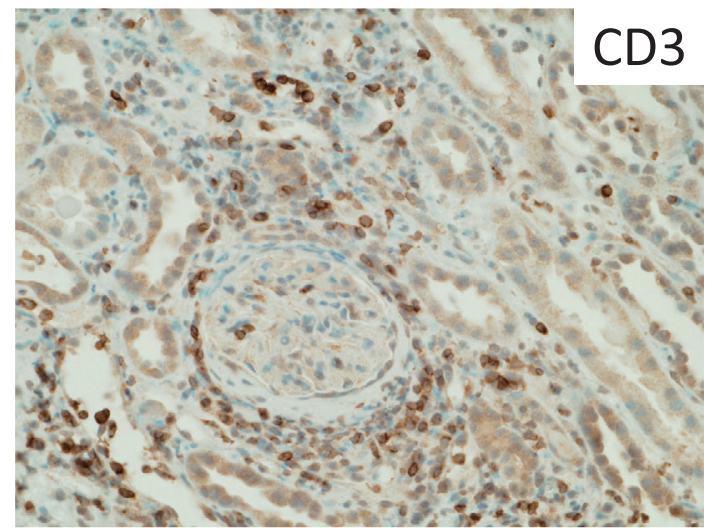

Figure 2. CD3+ positive cells among the infiltrating lymphocytes shown by CD3+ antibody.

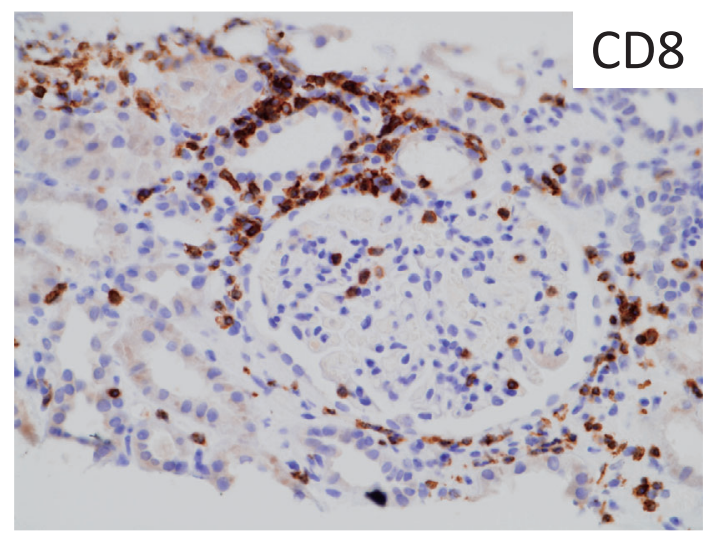

Figure 3. CD8+ positive cells among the infiltrating lymphocytes shown by CD8+ antibody.

and very few CD20+ cells in the interstitium. Electron microscopy showed segmental effacement of foot processes and electron-microscopic sclerosis, but no immune deposits or virus particles. EBV-encoded RNA 1 (EBER-1) in situ hybridization staining for the detection of EBV was negative. The appearance of the biopsy suggested acute tubulointerstitial nephritis, which was thought to be associated with EBV infection.

On the 19th-hospital day, there was no longer any need for renal replacement. As the corticosteroid dosage was reduced, the serum EBV level gradually decreased. However, when corticosteroid therapy was stopped 14 days after initiation, fever and rash returned, suggesting that treatment had been insufficient and that live virus was still active. Restarting prednisolone (60 mg daily) for 2 weeks alleviated these symptoms. Prednisolone was then tapered by $10 \mathrm{mg}$ daily every week until a maintenance dose was reached (15 mg daily). Serum creatinine level was stable but serum EBV DNA remained at several hundred copies per $10^{5}$ cells (Fig. 4). He was discharged in good condition and continued regular office visits for monitoring of blood EBV load.

\section{Discussion}

Infectious mononucleosis is characterized by the classical triad of pharyngitis, fever and lymphadenopathy (3). The diagnosis of a primary EBV infection rests upon one or more of the following serological criteria: 1) early detection and subsequent decline (if paired sera were examined) of antiEBV VCA IgM, 2) 4-fold or greater rise of anti-EBV VCA IgG during the course of the disease, 3) transient anti-EBV EA IgG, 4) early presence of anti-VCA IgG concurrent with early absence and later emergence of anti-EBV NA $\operatorname{IgG}(4,5)$.

Although subclinical urinary abnormalities including hematuria and proteinuria have been reported in $11 \%$ of cases of infectious mononucleosis, Lee and Kjellstrand (6) reported acute renal failure to be very uncommon in patients with EBV infection with a prevalence of approximately $1.6 \%$. The vast majority of cases showed tubulointerstitial nephritis.

Mayer et al reviewed 27 cases with EBV-associated renal failure, 12 of which had renal biopsy, and 10 of which showed tubulointerstitial nephritis (7). They found suppressor/cytotoxic $\mathrm{T}$ lymphocytes to be predominant in the interstitial infiltrates. Other rare conditions, such as acute rhabdomyolysis, minimal change nephritic syndrome, hemolytic anemia and hyperuricemia were also reported as related to EBV infection. Tsai et al (1) reported 8 of 165 hospitalized patients $(4.8 \%)$ had EBV-related primary acute renal failure, all of which were diagnosed with primary EBV infection serologically, 5 of whom had renal biopsy that showed acute tubulointerstitial nephritis. Glomerular abnormalities such as immune-complex mediated glomerulonephritis, membranous nephropathy or minimal change nephritic syndrome have also been reported but are thought to be very rare $(8,9)$.

After the review of Mayer et al in 1996 (7), we found only 10 EBV infection case reports which include histopathological findings from renal biopsy (Table 2). Nine of them had tubulointerstitial nephritis, and one also had concomitant focal mesangial proliferative glomerulonephritis. The remaining one case was not diagnosed with tubulointerstitial nephritis, probably because it also had poststreptococcus acute glomerulonephritis. The present patient showed patchy infiltration by mononuclear cells in the interstitial space with tubular atrophy (Fig. 1), which suggests acute tubulointerstitial nephritis.

Becker et al reported direct EBV infection in renal proximal tubular cells by in situ hybridization (ISH) in patients with idiopathic chronic tubulointerstitial nephritis (10). In our case, ISH EBER-1 did not detect the presence of EBV in the interstitium, but the finding of tubulointerstitial nephritis matched the previous reports. In the present case, reactive tubulointerstitial nephritis seemed to be predominant. Symptoms of infectious mononucleosis are thought to be immunopathological, caused by cytokine secretion from the activated cytotoxic (CD8+) T lymphocytes. The present case 


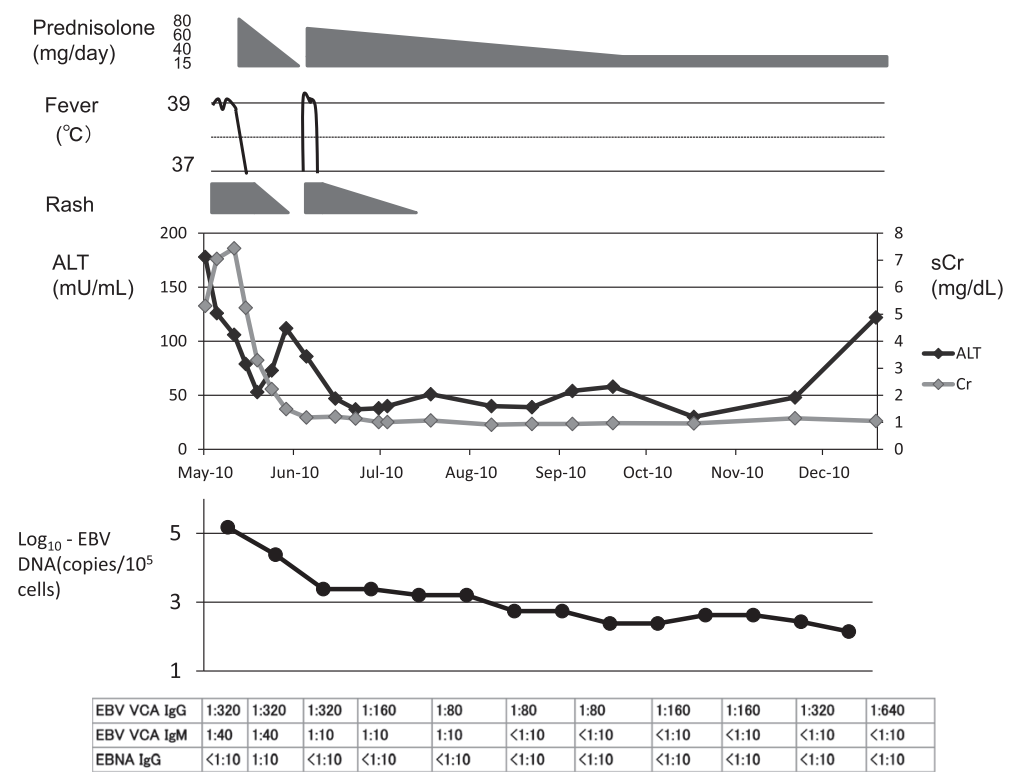

Figure 4. Clinical course and time course of EBV load.

Table 2. Case Reports of EBV-related Kidney Injury

\begin{tabular}{|c|c|c|c|c|c|c|c|c|c|c|c|c|}
\hline Publication & & Age & Sex & Clinical diagnosis & $\begin{array}{l}\mathrm{sCr} \text { at } \\
\text { presentat- } \\
\text { ion }(\mathrm{mg} / \mathrm{dl})\end{array}$ & $\begin{array}{l}\text { Renal pathology(Light } \\
\text { microscopy) }\end{array}$ & $\begin{array}{l}\text { Detection } \\
\text { of EBV in } \\
\text { renal } \\
\text { specimen }\end{array}$ & Site of EBV & $\begin{array}{l}\text { Characteristics of } \\
\text { infiltrate cells }\end{array}$ & Complications & Therapy & Outcome \\
\hline $\begin{array}{l}\text { Joh } \mathrm{K} \text { et } \\
\text { al }(8)\end{array}$ & 1998 & 7 & $\mathrm{~F}$ & $\begin{array}{l}\text { Proteinuria and } \\
\text { microscopic } \\
\text { hematuria }\end{array}$ & 0.2 & $\begin{array}{l}\text { Tubulointerstitial } \\
\text { nephritis } \\
\text { Immune complex- } \\
\text { mediated } \\
\text { glomerulonephritis }\end{array}$ & $(+)^{*}$ & $\begin{array}{l}\text { in the nuclei } \\
\text { of the } \\
\text { tubular } \\
\text { epithelial cells }\end{array}$ & $\begin{array}{l}\text { CD20+ > CD68+ } \\
\text { >>CD45RO } \\
\text { lymphoid cells }\end{array}$ & CAEBV & $\begin{array}{l}\mathrm{mPSL} \text { pulse } \\
\text { therapy(1g/day over } \\
\text { 3days) }\end{array}$ & ND \\
\hline $\begin{array}{l}\text { Lei PS et } \\
\text { al(17) }\end{array}$ & 2000 & 17 & M & ARF & 11.2 & $\begin{array}{l}\text { Tubulointerstitial } \\
\text { nephritis }\end{array}$ & $(+)$ & ND & $\begin{array}{l}\text { CD8+ T } \\
\text { lymphocyte } \\
>>\text { CD20+ }\end{array}$ & $\begin{array}{l}\text { JRA } \\
\text { jaundice } \\
\text { hemolytic anemia } \\
\text { thrombocytopenia }\end{array}$ & $\begin{array}{l}\text { HD } \\
\text { mPSL1g/day for } 4 \\
\text { consecutive days, followed } \\
\text { by oral corticosteroid in a } \\
\text { tapering dose for } 30 \text { days }\end{array}$ & $\begin{array}{l}\text { rapid } \\
\text { improving(nor } \\
\text { I mal renal } \\
\text { function one } \\
\text { month later) }\end{array}$ \\
\hline $\begin{array}{l}\text { Cataudella } \\
\text { JA et al (18) }\end{array}$ & 2002 & 18 & M & ARF & 15.7 & $\begin{array}{l}\text { Acute interstitial } \\
\text { nephritis }\end{array}$ & $(+)$ & $\begin{array}{l}\text { in occasional } \\
\text { interstitial } \\
\text { mononuclear } \\
\text { cells }\end{array}$ & $\begin{array}{l}\mathrm{CD} 8+\mathrm{T} \\
\text { lymphocyte=CD68 } \\
+>>\mathrm{CD} 4+\text { or } \\
\mathrm{CD} 20+\end{array}$ & ND & $\begin{array}{l}\mathrm{HD} \\
\text { Prednisone } 60 \mathrm{mg}\end{array}$ & $\begin{array}{l}\text { temporary HD, } \\
\mathrm{Cr} 13.8- \\
>0.85 \mathrm{mg} / \mathrm{dl}\end{array}$ \\
\hline $\begin{array}{l}\text { Okada H et } \\
\text { al(19) }\end{array}$ & 2002 & 70 & $\mathrm{~F}$ & $\begin{array}{l}\text { ARF } \\
\text { nephrotic range } \\
\text { proteinuria }\end{array}$ & 2 & $\begin{array}{l}\text { Acute tubulointerstitial } \\
\text { nephritis }\end{array}$ & $(+)$ & $\begin{array}{l}\text { in the } \\
\text { infiltrating } \\
\text { lymphocyte }\end{array}$ & ND & $\begin{array}{l}\text { MCNS } \\
\text { CAEBV }\end{array}$ & Spontaneous & $\begin{array}{l}\text { spontaneous } \\
\text { recovery }\end{array}$ \\
\hline $\begin{array}{l}\text { Verma } N \text { et } \\
\text { al(20) }\end{array}$ & 2002 & 41 & $\mathrm{~F}$ & $\begin{array}{l}\text { cold agglutinin- } \\
\text { induced } \\
\text { hemolytic anemia, } \\
\text { ARF }\end{array}$ & 4.6 & $\begin{array}{l}\text { Acute tubulointerstitial } \\
\text { nephritis }\end{array}$ & $\begin{array}{l}\text { not } \\
\text { performed }\end{array}$ & not performed & $\begin{array}{l}\text { T lymphocyte } \\
\text { CD20 negative }\end{array}$ & $\begin{array}{l}\text { Cold agglutinin- } \\
\text { induced hemolytic } \\
\text { anemia }\end{array}$ & $\begin{array}{l}\text { HD } \\
\text { Steroids(mPSL 60mg q6h } \\
\text { x2 days, followed by } \\
\text { 40mg/day) }\end{array}$ & $\begin{array}{l}\text { temporary } \\
\text { HD , recovery }\end{array}$ \\
\hline $\begin{array}{l}\text { Norwood VF } \\
\text { et al(21) }\end{array}$ & 2002 & $1 \& 1 / 3$ & & Renal failure & 3.7 & $\begin{array}{l}\text { Acute tubulointerstitial } \\
\text { nephritis } \\
\text { Acute tubular necrosis }\end{array}$ & $(-)$ & negative & $\begin{array}{l}\text { T lymphocyte } \\
\text { CD20 negative }\end{array}$ & ND & $\begin{array}{l}\mathrm{mPSL}(10 \mathrm{mg} / \mathrm{kg} \text { per day) } \\
\text { was given for } 3 \text { days }\end{array}$ & $\begin{array}{l}\text { recovery, } \\
\text { dialysis was } \\
\text { discontinued }\end{array}$ \\
\hline $\begin{array}{l}\text { Tsai JD et } \\
\text { al(1) }\end{array}$ & 2003 & ND & ND & $\begin{array}{l}\text { Proteinuria and } \\
\text { microscopic } \\
\text { hematuria, pyuria, } \\
\text { mild glucosuria, } \\
\text { concentrating } \\
\text { defect }\end{array}$ & 5.4 & $\begin{array}{l}\text { Acute interstitial } \\
\text { nephritis }\end{array}$ & ND & ND & $\begin{array}{l}\text { Lymphoplasma } \\
\text { cell and eosinophil }\end{array}$ & ND & Supportive treatment & recovered \\
\hline $\begin{array}{l}\text { Tsai JD et } \\
\text { al(1) }\end{array}$ & 2003 & ND & ND & $\begin{array}{l}\text { Proteinuria,micro } \\
\text { scopic hematuria }\end{array}$ & 4.3 & $\begin{array}{l}\text { Acute interstitial } \\
\text { nephritis }\end{array}$ & ND & ND & ND & ND & Supportive treatment & recovered \\
\hline $\begin{array}{l}\text { Kano K et } \\
\text { al(22) }\end{array}$ & 2005 & 11 & $\mathrm{~F}$ & $\begin{array}{l}\text { Hematuria and } \\
\text { proteinuria }\end{array}$ & 0.5 & $\begin{array}{l}\text { Focal mesangial } \\
\text { proliferative } \\
\text { glomerulonephritis } \\
\text { Acute interstitial } \\
\text { nephritis }\end{array}$ & $(+)$ & $\begin{array}{l}\text { in the } \\
\text { intravascular } \\
\text { spaces }\end{array}$ & $\begin{array}{l}\text { T lymphocyte } \\
\text { CD20 negative }\end{array}$ & $\begin{array}{l}\text { Aortic regurgitation } \\
\text { Annuloaortic } \\
\text { ectasia } \\
\text { Sinus of Valsalva } \\
\text { aneurysm } \\
\text { CAEBV } \\
\text { NK cell leukemia }\end{array}$ & $\begin{array}{l}\text { PSL(0.5-1.0mg/kg/d) and } \\
\text { dipyridamole. } \\
\text { To CAEBV; PSL, } \\
\text { etoposide, cyclosporin }\end{array}$ & $\begin{array}{l}\text { died of } \\
\text { interstitial } \\
\text { pneumonia } \\
\text { and NK cell } \\
\text { leukemia } 18 \\
\text { months after } \\
\text { the } 1 \text { st } \\
\text { admission }\end{array}$ \\
\hline $\begin{array}{l}\text { Subat- } \\
\text { De'ulovic M } \\
\text { et al(12) }\end{array}$ & 2010 & 11 & M & $\begin{array}{l}\text { Acute nephritic } \\
\text { syndrome(s-Cr } \\
1.26 \mathrm{mg} / \mathrm{dl})\end{array}$ & 1.26 & $\begin{array}{l}\text { Endocapillary } \\
\text { glomerulonephritis }\end{array}$ & $(+)$ & ND & T lymphocyte & $\begin{array}{l}\text { Post-infectious } \\
\text { glomerulonephritis } \\
\text { (Group A } \beta- \\
\text { hemolytic } \\
\text { streptococcus) }\end{array}$ & $\begin{array}{l}\text { Supportive,furosemid and } \\
\text { oral penicillin } \mathrm{V}\end{array}$ & $\begin{array}{l}\text { recovery, renal } \\
\text { function } \\
\text { remains stable }\end{array}$ \\
\hline
\end{tabular}

*EBV was detected by in situ hybridization EBER-1 of PCR technique. ND: not described, ARF: acute renal failure, CAEBV: chronic active EBV infection, JRA: juvenile rheumatoid arthritis, MCNS: minimal change nephrotic syndrome, HD: hemodialysis, PSL: prednisolone, mPSL: methylprednisolone.

had preceding antibiotics exposure and hypoxemia, so it is difficult to exclude these factors as a cause of tubulointerstitial changes. However, in the usual case of acute tubu- lointerstitial nephritis, including drug-induced nephritis, interstitial infiltrates are mostly CD4+ lymphocytes, macrophages, eosinophils and plasma cells (11). The subtype of 
infiltrate is not specific but active cytotoxic (CD8+) T lymphocytes play a pivotal role in EBV-related acute tubulointerstitial nephritis. It is said that cytotoxic (CD8+) $\mathrm{T}$ lymphocytes recognizing several EBV antigens invade the peritubular interstitium to cause an antigen-directed cellmediated immune response (12).

One of the clinical problems of infectious mononucleosis is the management of fulminant cases. Immunosuppressive medications such as corticosteroids have not been shown to be effective against this virus-associated tubulointerstitial nephritis, but concomitant hepatic and respiratory failure prompted us to administer high dose corticosteroid. We consider that corticosteroid was at least effective for the skin eruption and constitutional symptoms, because the overly rapid reduction of corticosteroid caused relapse of fever and rash. Corticosteroid may have a significant therapeutic role in a few selected patients with severe malaise, fever, severe central nervous system complications or cardiac disease. Hypercytokinemia may be related to the fact of whether corticosteroids are effective. Acyclovir does not seem to decrease EBV load and has had no clinical impact on the management of infectious mononucleosis. Acyclovir is reportedly effective for respiratory complications such as airway obstruction or pharyngitis, but more data are necessary to prove whether it is effective in the treatment of damage to other organs $(11,13,14)$.

Another interesting aspect of the present patient is whether he will have some future complications or sequelae after such a serious primary EBV infection attributable to the oncogenic property of this virus. Chronic active EBV infection syndrome (CAEBV) is known to be a serious feature of EBV infection and is characterized by chronic or recurrent infectious mononucleosis-like symptoms, abnormal antiEBV antibody patterns and increased EBV load in the peripheral blood. Our patient is still positive for peripheral blood EBV DNA. Using DNA PCR analysis, Khan et al (15) reported that $10-460$ per $10^{7}$ EBV-infected B cells remained in the peripheral blood of 15 healthy but chronically infected individuals. We cannot determine whether the blood EBV DNA indicates infection in B cells or T/NK cells. However, we consider that the present case is the natural virological course because the linear logarithmic regression of his viral load suggests that he is already out of the lytic viral replication phase.

$\mathrm{X}$-linked lymphoproliferative syndrome, in which primary EBV infection results in a fatal outcome, was recently shown to have a mutation in SH2D1A (the SH2 domaincontaining 1A gene). Although the present patient did not show erythrophagocytosis, cytopenia, hypogammaglobulinemia or lymphoma, this possibility still remains, so follow-up is necessary (16).

In summary, we encountered a rare case of fulminant infectious mononucleosis with acute EBV-related tubulointerstitial nephritis as an interesting pathological feature. We are concerned about the possibility of progression to chronic active EBV infection or hematological malignancies, so care- ful follow-up of the EBV load is needed.

The authors state that they have no Conflict of Interest (COI).

\section{Acknowledgement}

A part of this case report was presented at the 575th Kanto Meeting of the Japanese Society of Internal Medicine. Dr. Wilfred Y. Fujimoto (Division of Metabolism, Endocrinology and Nutrition, University of Washington School of Medicine) kindly checked this paper.

\section{References}

1. Tsai JD, Lee HC, Lin CC, Liang DC, Chen SH, Huang FY. Epstein-Barr virus-associated acute renal failure: diagnosis, treatment, and follow-up. Pediatr Nephrol 18: 667-674, 2003.

2. Johannsen EC, Schooley RT, Kaye KM. Epstein-Barr virus (infectious mononucleosis). In: Mandell, Douglas, and Bennett's Principles and Practice of Infectious Diseases. 6th ed. Elsevier Churchill Livingstone, Philadelphia, 2005: 1801-1820.

3. Hurt C, Tammaro D. Diagnostic evaluation of mononucleosis-like illnesses. Am J Med 120: 911.e1-911.e8, 2007.

4. Henle W, Henle G, Horwitz CA. Epstein-Barr virus specific diagnostic test in infectious mononucleosis. Hum Pathol 5: 551-565, 1974.

5. Sumaya CV, Ench Y. Epstein-Barr virus infectious mononucleosis in children. I. Clinical and general laboratory findings. Pediatrics 75: 1003-1010, 1985.

6. Lee $\mathrm{S}$, Kjellstrand CM. Renal disease in infectious mononucleosis. Clin Nephrol 9: 236-240, 1978.

7. Mayer HB, Wanke CA, Williams M, et al. Epstein-Barr virusinduced infectious mononucleosis complicated by acute renal failure: case report and review. Clin Infect Dis 22: 1009-1018, 1996.

8. Joh K, Kanetsuna Y, Ishikawa Y, et al. Epstein-Barr virus genomepositive tubulointerstitial nephritis associated with immune complex-mediated glomerulonephritis in chronic active EB virus infection. Virchows Arch 432: 567-573, 1998.

9. Araya CE, Gonzalez-Peralta RP, Skoda-Smith S, et al. Systemic Epstein-Barr virus infection associated with membranous nephropathy in children. Clin Nephrol 65: 160-164, 2006.

10. Becker JL, Miller F, Nuovo GJ, et al. Epstein-Barr virus infection of renal proximal tubule cells: possible role in chronic interstitial nephritis. J Clin Invest 104: 1673-1681, 1999.

11. Praga M, González S. Acute interstitial nephritis. Kidney Int 77: 956-961, 2010.

12. Subat-Dezulović M, Dessardo NS, Dezulović M, Dessardo D, Hadzisejdić I, Brncic N. Postinfectious glomerulonephritis and Epstein-Barr virus co-infection. Coll Antropol 34: 229-232, 2010.

13. McGowan JE Jr, Chesney PJ, Crossley KB, LaForce FM. Guidelines for the use of systemic glucocorticosteroids in the management of selected infections. J Infect Dis 165: 1-13, 1992.

14. Sudderick RM, Narula AA. Steroids for airway problems in glandular fever. J Laryngol Otol 101: 673-675, 1987.

15. Khan G, Miyashita EM, Yang B, Babcock GJ, Thorley-Lawson DA. Is EBV persistence in vivo a model for B cell homeostasis? Immunity 5: 173-179, 1996.

16. Rezaei N, Mahmoudi E, Aghamohammadi A, Das R, Nichols KE. $\mathrm{X}$-linked lymphoproliferative syndrome: a genetic condition typified by the triad of infection, immunodeficiency and lymphoma. Br J Haematol 152: 13-30, 2010.

17. Lei PS, Lowichik A, Allen W, Mauch TJ. Acute renal failure: unusual complication of Epstein-Barr virus-induced infectious mononucleosis. Clin Infect Dis 31: 1519-1524, 2000.

18. Cataudella JA, Young ID, Iliescu EA. Epstein-Barr virusassociated acute interstitial nephritis: infection or immunologic 
phenomenon? Nephron 92: 437-439, 2002.

19. Okada H, Ikeda $N$, Kobayashi $T$, et al. An atypical pattern of Epstein-Barr virus infection in a case with idiopathic tubulointerstitial nephritis. Nephron 92: 440-444, 2002.

20. Verma N, Arunabh S, Brady TM, Charytan C. Acute interstitial nephritis secondary to infectious mononucleosis. Clin Nephrol $\mathbf{5 8}$ : 151-154, 2002.
21. Norwood VF, Sturgill BC. Unexplained acute renal failure in a toddler: a rare complication of Epstein-Barr virus. Pediatr Nephrol 17: 628-632, 2002.

22. Kano K, Yamada Y, Sato Y, Arisaka O, Ono Y, Ueda Y. Glomerulonephritis in a patient with chronic active Epstein-Barr virus infection. Pediatr Nephrol 20: 89-92, 2005.

(C) 2012 The Japanese Society of Internal Medicine http://www.naika.or.jp/imindex.html 